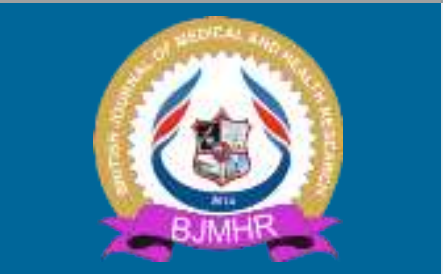

\title{
BJMHR
}

British Journal of Medical and Health Research Journal home page: www.bjmhr.com

\section{Effect of Efficient Recruitment and Adaptation Training On Promotion in A Private Healthcare Organization-Campus Program Example in Turkey}

\author{
Fikri Kiper ${ }^{1}$, Gülfer Bektaş ${ }^{2}$, Birkan Tapan ${ }^{3 *}$ \\ 1.Acıbadem Healthcare Group, Department of Human Resources, Istanbul, Turkey. \\ 2.Acıbadem Mehmet Ali Aydinlar University, School of Health Sciences, Department of \\ Healthcare Management, Istanbul, Turkey. \\ 3.Demiroglu Bilim University, Vocational High School of Health Services, Healthcare \\ Organizations Management, Istanbul, Turkey.
}

\section{ABSTRACT}

Organizations can only get optimum benefit from their most important source 'Human Resources (HR)' if they bring in, keep and develop them even further which would allow organizations to reach their targets and join in a rivalry. This study reviews recruitment processes for patient services personnel of a private healthcare organization, assesses adaptation training, and analyzes the effects on promotion. The patient services personnel recruited in the mentioned healthcare organization may directly start to work, or the candidates may be given an adaptation training and start working in branches after going through a specific training program. 434 people were recruited as patient services personnel in 2015, and participated in an orientation training called "Campus Program." When the number of patient complaints in two branches of the healthcare organization was analyzed, the rate of complaints per employee that did not graduate from the Campus Program (non-graduates) was found to be 2.83; while the rate of complaints per employee that graduated from the Campus Program (graduates) was 0.30 in the first branch. In the second branch, the rate of complaints per nongraduate employee was 5.89, while the rate of complaints per graduate employee was 0.07 in the first branch. According to the data for the end of 2015, personnel turnover rate was realized as $18 \%$ for Campus Program graduates and $22 \%$ for Patient Services personnel. Annual personnel turnover rate for the same occupational group was 26\% in 2014 and $24 \%$ in 2013.

Keywords: hospital, human resources, recruitment, promotion, patient services

*Corresponding Author Email: birkantapan@gmail.com

Received 06 January 2020, Accepted 27 January 2020

Please cite this article as: Tapan B et al., Effect of Efficient Recruitment and Adaptation Training On Promotion In A Private Healthcare Organization-Campus Program Example In Turkey. British Journal of Medical and Health Research 2020. 


\section{INTRODUCTION}

The main target of organizational sources could be classified as money, personnel, place, equipment and time. Of those, the most important and the most difficult to maintain is human resources. This is because human provides and manages all the other sources, and has extensive control over the input.

Managers would like to appoint talented candidates as this not only would enable them to achieve their targets but also it would increase the productivity and profitability within the organization. Those appointed candidates are being recruited for both to work for specific tasks and to support achieving organizational success. It is obvious that human resources are really important for an organization and it is very important to make the most of employees' talent, ability and their opinions. ${ }^{1}$

We all know that the service industry, especially the health sector, moves, develops and transforms very rapidly. The aim to achieve the expected quality of the service and the customer satisfaction, the behavior and the manner of the employees is even more important than it was in the previous years. The companies serving in this industry are well aware that the most valuable capital is the human resources, and customer satisfaction is as important as the employee satisfaction.

It is a very critical issue to set the organizational commitment, to increase the employee satisfaction and to bring the resignation reasons to minimum. Once these are all achieved, it is expected to see an increase in customer satisfaction and the quality of the service that the employees provide will affect the organizational success in a positive way. ${ }^{2}$

Especially in the health organizations, human resources management is paramount for controlling the number and the quality of the employees, their training, development, personnel affairs, performance management and career planning. In this article, the truth of this statement will be assessed based on the model of a private health organization acting across Turkey through investigating its orientation program to establish the relation between the post recruitment training and the organizational commitment.

Searching and selection functions for vacant positions are critical for the development of the organization. ${ }^{3}$ Therefore, in order to hire the right person, right recruitment methods should be used.

This study focuses on how the performance and organizational loyalty would be affected by using effective tools to select the right person for a vacancy from either internal or external candidates and applying orientation training programs following the start of employment to help familiarization within the organization. 
In health sector organizations, employee performance would be directly affected from organizational loyalty. It is crucial to select employees by using relevant tools and to provide orientation training programs from the first day to increase loyalty effectively.

\section{METHODOLOGY AND DESIGN:}

The organization mentioned above has introduced a program called Campus Program in 2015. In this study, the stages of the program were investigated and as a result established the effect to the personnel turnover, productivity and organizational commitment.

The methodology of this research is sample case investigation. It involves a detailed investigation of one or more cases. It is possible to use one of the tools to collect information by face to face interviews, observations or experiments.

There are two ways of sample case investigation; first one entails investigating the historical case of an organization. This would focus on a specific organization and its development over time. The main sources would be the interviews with relevant people from the organization, observations of the current status and written documentations. The second type of sample case investigation is based on observations. The main data collection source is attendance observation. The base would be the organization. ${ }^{4}$

By following the theoretical information, this study discusses the recruitment process of this private health organization and its effect on post recruitment training.

\section{Campus Program}

Since 2015, the organization mentioned above has introduced a post recruitment training which lasts for a month, specifically designed for medical admission personnel.

Campus program is a training program employed to raise the medical admission personnel in a well-equipped manner in addition to technical and personal competencies who is able to contact patients on a one-to-one basis.

The main target is to improve occupational and personal competencies in private simulation rooms. By this way, it is expected for the employees to gain more practice and familiarity during the adaptation process.

Technical training is also being provided for the software that is set up during their training. It takes place in the same set up training rooms within hospital polyclinics.

Before the program, the required number of human resources and their qualities are evaluated. The advertisement is being published on organizational HR website, social media and the other recruitment portals. Following the evaluations of all the applications, the selected candidates are being interviewed by the HR department and relevant managers.

Following the interviews, the candidates are required need to complete personality tests and general ability tests. This would analyze their personality as to whether they are suitable for 
the job. The reference controls for a candidate are completed who passed all stages. The process ends with a job offer.

The campus program starts with the organizational orientation training and main patient services information. It continues with communication and behavior trainings.

During the program, the attendants are being informed about the organizational structure, job descriptions, dress code, tax and insurance, SGK (Sosyal Guvenlik Kurumu-Social Security Administration-SSA) terminology, provision stages, billing stages, employee health and safety. They also receive some personal development training on communication, patient relations, stress management and team work.

All attendants are daily examined for the learnings of the previous day. This amounts to five exams per week, and a total of twenty-five exams.

The training takes place in classrooms for four days in a week and twice a week at hospitals. The aim is to grant the participants the chance to observe the relevant departments and to gain practical experience on top of their theoretical information.

The classroom training is supported with real case samples.

Attendants are evaluated on their exam scores, observation notes from the hospital orientations and management feedback. If a candidate fails to reach a desirable result, an additional feedback interview will take place.

Following the feedback meetings if the attendant still fails to achieve the required performance score, an exit interview takes place. On the other hand, those who successfully complete the program will be awarded a certificate and will receive their job offers.

\section{RESULTS AND DISCUSSION}

In 2015, 434 candidates, who attended the campus program for post recruitment adaptation training, were appointed for patient services vacancies. By the end of 2015, 86\% of the graduates from the program is still working for the organization as shown Figure 1.

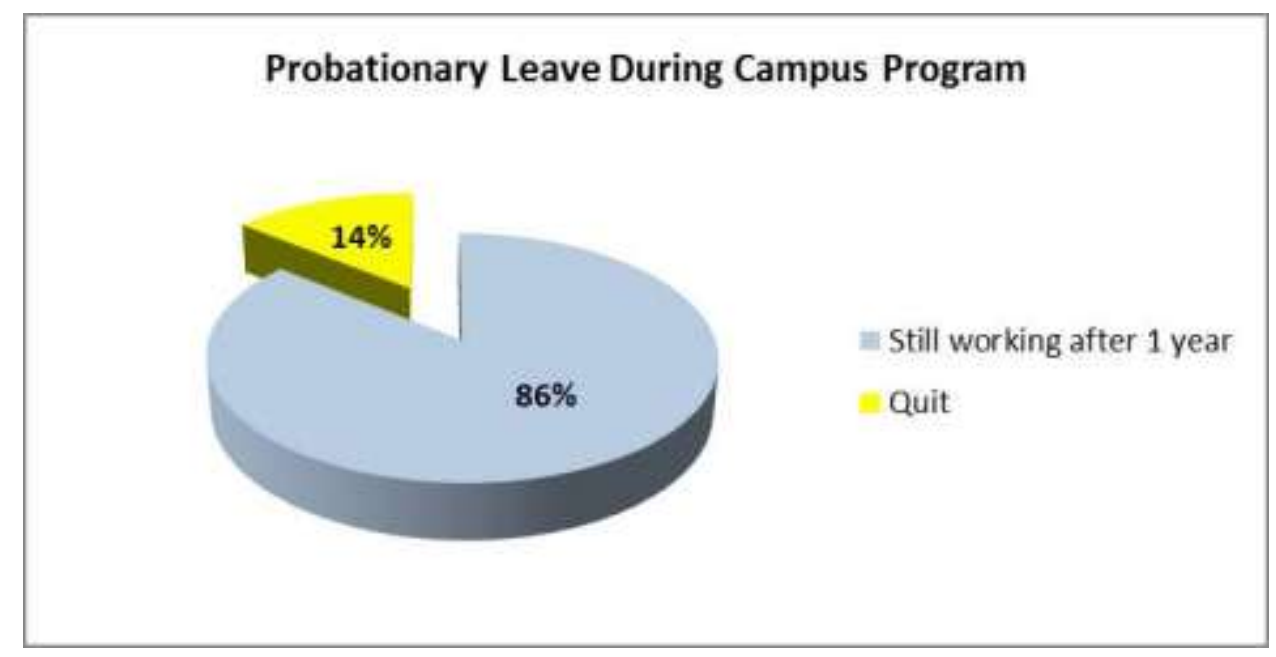

Figure 1: Probationary leave ratio during campus program 
The same private hospital is giving the title "competent" for the candidates that were appointed for the patient services vacancies and who passed the relevant exams following the technical and vacation information training sessions. According to the "competency" exams results in 2015, the graduates from the Campus Program are getting $4.4 \%$ better results than the employees who have been appointed outside of this program and been working for the group for 6-12 months already.

During the considerations of two separate branches of the hospital, it is established that in the first branch, the percentage of the complaints by the non-graduates from the Campus Program was $2.83 \%$, whereas by the graduates this percentage was $0.30 \%$. Likewise, at the second branch, the percentage of the complaints by the non-graduates was $5.89 \%$ and by the graduates was $0.07 \%$.

The candidates who are meeting with the sector for the first time, the orientation process is being prepared in a simulation environment. This was aimed at increasing the knowledge and the experience of a new employee in a quick manner. Following a training based recruitment program, the career planning process for candidates who are being offered the job, is controlled in parallel with their vacation mandatory training lists.

According to the last "competency" exam, the graduates from the Campus Program were more successful with regards to the vacation and personal competencies than the non-graduates.

According to the measurements of the complaints; it is established that the graduates are receiving $8.35 \%$ less complaints in a year than the non-graduates. Therefore it is agreed that the Campus program graduates are very supportive to the organizational customer satisfaction results.

As shown Fig 2, by the end of 2015, the turnover of the Campus Program graduates was $18 \%$ where the patient services employee turnover was $22 \%$. Likewise, for the same vacancy group, the results were $26 \%$ in 2014 and $24 \%$ in 2013.

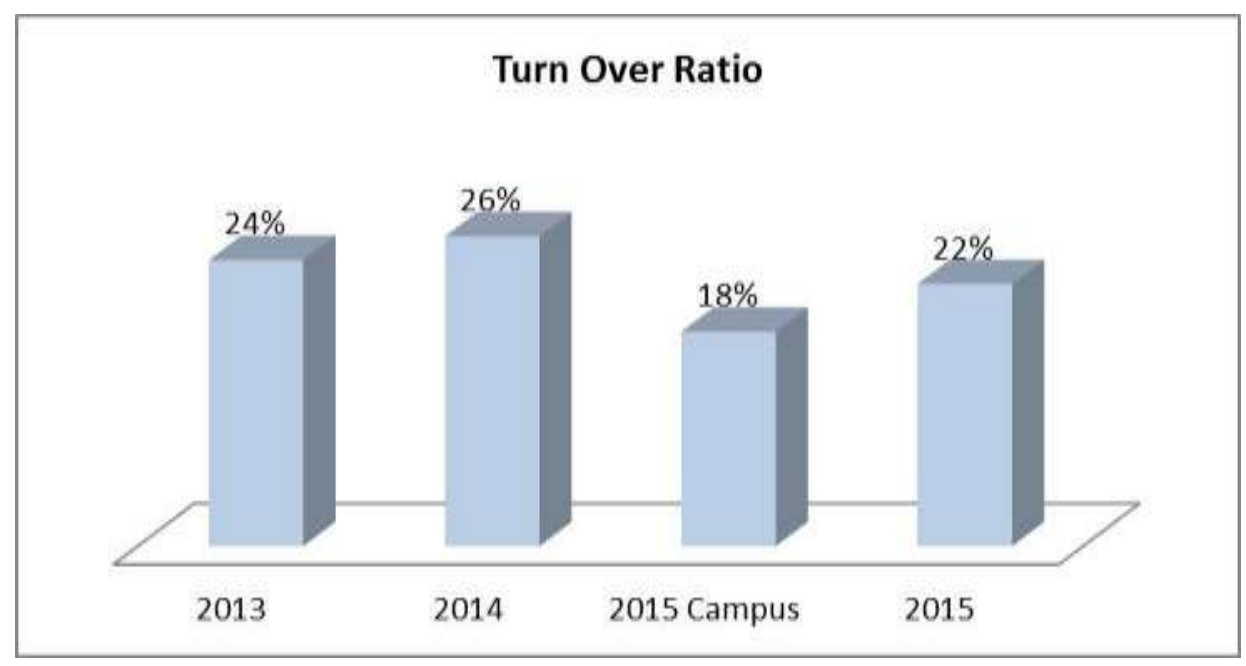

Figure 2: Personnel turnover ratio in a private hospital 


\section{DISCUSSION:}

Nowadays, it is obvious that organizations should acknowledge their most valuable entity as their employees. If they use this entity efficiently and effectively, they can then achieve their competitive targets.

A recruitment process based on objective principles creates an environment of trust against the institution, and it provides the opportunity to reach the goals of the institution faster by selecting the best among the candidates. ${ }^{5}$

One of the most important tasks of the human resources departments and the managers is not only to find the informative, talented, capable and also motivated human resources, but also to be able to keep the consistency.

It is essential to manage the recruitment process effectively to be able to appoint right people for the right job. It is necessary to plan the human resources, identify the required specification, analysis and the using the right tools to find the candidates. Likewise, an effective interview stage would affect the whole process.

Every single recruitment criteria would differentiate for each vacancy. The required competencies and recruitment criteria should be identified in advance. This will allow managers to recruit competent candidates who are suitable for the organization. ${ }^{6}$

Many organizations are neglecting the post recruitment orientation stages. An effective recruitment program would play an active role in a faster adoption process for a new employee. The employee could only adapt to the organizational culture and provides good performance. This would end up with a high organizational commitment.

Especially within a health sector company, the organization commitment and satisfaction would have a direct effect on the performance and most importantly on the quality of the service provided to the patients. Therefore, private health organizations should use the right selection process for the candidates, appoint the right people to the right vacancies and should implement an adaptation training program beginning from the first day onwards.

According to the research, it is identified that if a private health sector company appoints the candidate with the right selection process and introduce the orientation program, these employees would stay with the company for a longer period. It is also identified that in this way, the number of resignations during the probation period would be lower and the number of patient complaints would be even less.

\section{CONCLUSION}

The organization mentioned above could either appoint a candidate directly from an application or following an orientation program and a series of training sessions. Having compared the two ways, it is identified that the attendants of the orientation program are not only working for the 
group for a longer period but also the percentage of resignation is lower than the directly appointed candidates. Given the fact that the patient expectations are much higher in the healthcare sector, it is necessary to appoint well performing and motivated employees to provide the expected service who also possess such organization commitment. This is because candidates can adapt to the organization even easier and quicker if they attend to adaptation training and their impression about the company would be positive.

\section{REFERENCES:}

1. Tortop N, Özer A, Aykaç B, Yayman H. İnsan Kaynakları Yönetimi. Istanbul: Nobel Yayın; 2013.

2. Gül H, Oktay E. İş Tatmini, Stres, Örgütsel Bağl1lık, İşten Ayrılma Niyeti ve Performans Arasındaki İlişkiler: Sağlık Sektöründe Bir Uygulama. Akademik Bakış; 2008, 15.

3. Barutçugil İ. Stratejik İnsan Kaynakları Yönetimi. İstanbul; Kariyer Yayınları; 2014.

4. Özkaya Z. Örnek Olay İncelemesi, Ankara Üniversitesi, Eğitim Bilimleri Enstitüsü Tezsiz Yüksek Lisans Programı Araştırma Yöntemleri Dersi Ödevi, Ankara; 2006.

5. Sabuncuoğlu Z. İnsan Kaynakları Yönetimi. Istanbul: Beta Yayınları; 2013.

6. Palmer M, Winters K. Human Resources. Istanbul: Rota Yayınlar1; 1993.

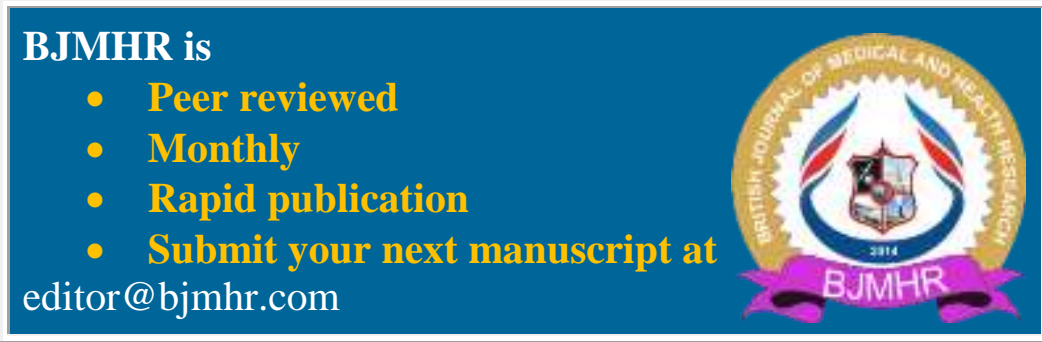

